\title{
STUDI KETERSEDIAAN N-TANAH DI SENTRA TANAMAN \\ BAWANG PUTIH (Allium sativum L.), KECAMATAN PUJON, MALANG, JAWA TIMUR
}

\author{
A Study of Soil N Availability in the Center of Garlic (Allium sativum \\ L.) Pujon District, Malang, East Java
}

\author{
Ketriwani Panggabean*, Soemarno \\ Jurusan Tanah, Fakultas Pertanian, Universitas Brawijaya, Jl. Veteran no 1 Malang, 65145 \\ *Penulis korespondensi: ketriwanipanggabean@gmail.com
}

\begin{abstract}
Pujon District is one of garlic centers for increasing garlic production in Malang. One of the causes of low garlic production is the low soil fertility. The status of soil fertility in garlic areas is influenced by availability of soil N. This study was conducted in Pujon District, Malang. The observation points were spread over five villages of garlic centers, i.e. Pandesari, Pujon Lor, Sukomulyo, Bendosari, and Madiredo. Correlation analysis was conducted for data of soil chemical and physical properties obtained from laboratory analysis. The garlic production was used as a dependent variable, while the soil N-total, C-organic, $\mathrm{pH}\left(\mathrm{H}_{2} \mathrm{O}\right), \mathrm{pH}(\mathrm{KCl})$, bulk density, and soil porosity, were used as the independent variables. Results showed that status of soil $\mathrm{N}$ the garlic center of Pujon District was in the low to medium category. Content of $\mathrm{N}$ in the topsoil $(0-30 \mathrm{~cm})$ of the five land mapping units was medium, while that in the subsoil $(30-60 \mathrm{~cm})$ of the five land mapping units ranged from low to medium. The large or small $\mathrm{N}$ content in the soil did not significantly correlated to organic $\mathrm{C}, \mathrm{pH}\left(\mathrm{H}_{2} \mathrm{O}\right.$ and $\left.\mathrm{KCl}\right)$, bulk density and soil porosity. There was a significant correlation between garlic production and the $\mathrm{C} / \mathrm{N}$ ratio. However, the significant correlation was only found in the lower layer $(30-60 \mathrm{~cm})$ with the $\mathrm{r}=0.82^{* *}$.
\end{abstract}

Keywords: garlic, soil nitrogen availability, soil properties

\section{Pendahuluan}

Kebutuhan (konsumsi) bawang putih dari tahun ke tahun meningkat sejalan dengan memeningkatnya jumlah penduduk di Indonesia (Hariwibowo, Anindita dan Suhartini, 2014). Namun, peningkatan ini belum mampu diimbangi dengan peningkatan produksi, hal ini disebabkan oleh luas tanam dan produktivitas yang rendah (Sarwadana dan Gunadi, 2007; Harinta dan Basuki, 2018). Produksi bawang putih di Indonesia hanya mampu memenuhi kebutuhan sebesar 5\%, sedangkan 95\% kebutuhan bawang putih di Indonesia masih dipenuhi dengan impor (BPS dan Direktorat Jendral Hortikultura,2015). Rendahnya produksi bawang putih lokal salah satu penyebabnya adalah produktivitas yang cukup rendah (Tenaya, 2001; Mehran et al., 2016; Wisardja et al., 2017). Terdapat beberapa lokasi yang telah ditetapkan oleh Kementrian Pertanian sebagai sentra penanaman bawang putih yang dilihat dari keberadaan wilayah yang sesuai untuk pertanaman bawang putih, dan juga keberadaan petani bawang putih yang menjadi salah satu nilai tambah. Provinsi Jawa Timur menjadi salah satu daerah fokus peningkatan produksi bawang putih oleh Kementrian Pertanian. Salah satu upaya untuk meningkatkan produksi bawang putih di Jawa 


\section{Jurnal Tanah dan Sumberdaya Lahan Vol 6 No 2 : 1415-1425, 2019 e-ISSN:2549-9793, doi: 10.21776/ub.jtsl.2019.006.2.22}

Timur, Balai Pengkajian Teknologi Pertanian (BPTP) melakukan penyebaran teknologi inovatif budidaya bawang putih ke daerahdaerah yang sesuai dengan syarat tumbuh tanaman bawang putih dan bekerjasama dengan Kelompok Tani di lokasi setempat (Sarwadana dan Gunadi, 2007). Kecamatan Pujon Kabupaten Malang menjadi salah satu sentra peningkatan produksi bawang putih di Kabupaten Malang. Kecamatan Pujon termasuk daerah penghasil bawang putih dalam kategori yang rendah. Diantara berbagai macam unsur hara yang dibutuhkan tanaman, nitrogen merupakan salah satu diantara unsur hara makro tersebut yang sangat besar peranannya bagi pertumbuhan dan perkembangan tanaman bawang putih (Zaman et al., 2011; Assefa et al., 2015; Bo et al., 2016).

\section{Bahan dan Metode}

Penelitian dilaksanakan pada bulan Oktober 2018 sampai dengan Januari 2019. Tempat penelitian terletak di Kecamatan Pujon, Kabupaten Malang. Titik pengamatan tersebar di lima sentra bawang putih yang ada di Kecamatan Pujon yaitu Desa Pandesari, Desa Pujon Lor, Desa Sukomulyo, Desa Bendosari, dan Desa Madiredo. Kegiatan analisis tanah dilakukan di Laboratorium Kimia dan Fisika Jurusan Tanah, Fakultas Pertanian, Universitas Brawijaya. Alat dan bahan untuk penelitian ini terdiri atas alat selama kegiatan lapang Global Positioning System (GPS), klinometer, survei set,alat tulis dan kamera. Alat untuk kegiatan laboratorium, antara lain alat-alat untuk analisis $\mathrm{N}$-total, pH, C-organik dan tekstur tanah. Alat untuk analisis data, antara lain aplikasi SPPS, Arc GIS 10.3, Ms. Excel 2013, Ms. Word 2013 dan Laptop. Bahan kegiatan penelitian ini, antara lain aquadest, bahan kimia, seperti $\mathrm{H}_{2} \mathrm{O}_{2}$ dan $\mathrm{HCl}$ untuk analisis fisika dan kimia tanah, Peta Rupa Bumi Digital Indonesia skala 1:25.000, Landsat 8-OLI/TIRS C1 Level 1: 118-65, Digital Elevation Model (DEM) SRTM 30 m Kecamatan Pujon Tahun 2018, peta jenis tanah, form pengamatan lapangan dan form wawancara petani.

Penelitian ini dilakukan dengan menggunakan metode survei yang terbagi kedalam beberapa tahap antara lain persiapan, prasurvei, pengamatan lapangan, analisis laboratorium dan analisis data. Kegiatan survei dilakukan dengan pengamatan lahan, groundcheck, dan wawancara dengan petani. Acuan kegiatan survei didasarkan pada peta SPL yang telah dibuat dengan faktor pembatas kemiringan lahan, jenis tanah, dan bentuk lahan yang tersebar di Kecamatan Pujon. Kemudian dilakukan penentuan titik dengan metode purposive sampling berdasarkan kriteria produksi tanaman bawang putih dan mempunyai aksesibilitas yang mudah dijangkau. Hasil kegiatan survei kemudian diolah dan dianalisis dengan analisis laboratorium tanah pada lahan bawang putih, dan analisis hubungan antara sifat-sifat tanah dengan produksi tanaman bawang putih. Penelitian ini dilaksanakan melalui beberapa tahapan-tahapan, yaitu : tahap persiapan, dimana pada tahap ini melakukan kegiatan administrasi berupa surat-surat perizinan untuk penelitian di Kecamatan Pujon yang diberikan kepada kantor kecamatan, kantor kepala desa, dan Badang Kesatuan Bangsa dan Politik (Bakesbangpol) Kota Malang, serta surat untuk perizinan analisis laboratorium di Jurusan Tanah, Fakultas Pertanian, Universitas Brawijaya. Tahap kegiatan prasurvei, pada kegiatan pra survei dilaksanakan dengan melakukan observasi daerah penelitian dan juga pembuatan peta kerja. Observasi daerah penelitian meliputi pengamatan kondisi aktual lahan, penentuan titik pengamatan, pencarian petani, dan mencari akses jalan untuk menuju titik pengamatan. Kemudian, dilakukan pembuatan peta kerja, yaitu peta administrasi dengan digitasi peta RBI 1:25.000 untuk mengetahui batas administratif dan akses jalan dilokasi penelitian. Pembuatan peta kelerengan yang didapatkan dari hasil pengolahan data DEM SRTM $30 \mathrm{~m}$ yang dikelola menggunakan aplikasi Arc GIS 10.3 yang diklasifikasikan menurut Djaenuddin et al. (2011) dikhususkan untuk tanaman bawang putih.

Tahap pengamatan lapangan dilakukan untuk melihat karakteristik lahan dan validasi data dengan cara pengamatan lahan, ground-check, pengambilan sampel, dan wawancara dengan petani. Ground-check dilakukan untuk klarifikasi dan validasi peta kerja dengan kondisi aktual di lapangan. Pengambilan sampel tanah dilakukan 


\section{Jurnal Tanah dan Sumberdaya Lahan Vol 6 No 2 : 1415-1425, 2019 e-ISSN:2549-9793, doi: 10.21776/ub.jtsl.2019.006.2.22}

dengan mengambil sampel tanah komposit lapisan atas (0-30 cm) dan lapisan bawah (30-60 $\mathrm{cm})$ pada 10 titik pengamatan yang tersebar di lima sentra penghasil bawang putih yaitu Desa Pandesari, Desa Pujon Lor, Desa Sukomulyo, Desa Bendosari, dan Desa Madiredo untuk selanjutnya dilakukan analisis sifat kimia dan fisika tanah serta wawancara dilakukan dengan menggunakan metode purposive sampling dengan mengacu pada peta kerja SPL dan hasil wawancara yang telah didapat dimana titik yang diamati ditentukan berdasarkan keberadaan tanaman bawang putih dan informasi sejarah lahan yang pernah ditanami bawang putih yang memiliki data produksi tanaman. Menurut Sugiyono (2003), metode purposive sampling merupakan teknik penentuan sampel dengan pertimbangan khusus sesuai tujuan penelitian.Survei produksi dan pengolahan lahan dilakukan dengan wawancara terhadap petani tiap titik pengamatan dengan kuisioner usahatani meliputi hasil panen, luas lahan, jarak tanaman, serta teknik budidaya petani. Kemudian dilakukan tahap analisis laboratorium yang dilakukan di Laboratorium Fisika dan Kimia Tanah, Fakultas Pertanian, Universitas Brawijaya. Selanjutnya, data yang diperoleh dari hasil analisis laboratorium mengenai sifat kimia dan fisika tanah untuk kemudian dilakukan analisis korelasi dan regresi dengan produksi sebagai peubah tak bebas dan unsur hara N-total, C-organik, Rasio $\mathrm{C} / \mathrm{N}, \mathrm{pH}$ $\mathrm{H}_{2} \mathrm{O}$ dan $\mathrm{pH} \mathrm{KCl,} \mathrm{BI} \mathrm{tanah,} \mathrm{Porositas} \mathrm{dan}$ Tekstur tanah sebagai peubah bebas. Analisis korelasi dengan aplikasi Statistical Package for The Social Sciences (SPSS) yang digunakan untuk mengetahui mengetahui ada tidaknya hubungan antar dua parameter pengamatan dalam suatu penelitian. Parameter yang memiliki keeratan kemudian dilakukan analisis regresi dengan Microsoft Excel 2013, untuk kemudian hasil dari regresi digunakan untuk mengetahui bentuk hubungan antar parameter.

\section{Hasil dan Pembahasan}

Hasil analisis sifat-sifat tanah dan produksi

N-total tanah

Berdasarkan hasil analisis yang dilakukan di kelima SPL, bahwa pada SPL 1 yang berada di
Desa Pandesari dan Desa Pujon Lor, nilai Ntotal pada lapisan tanah atas sebesar $0,25 \%$ dan pada lapisan tanah bawah sebesar 0,26\%. Nilai tersebut menunjukkan bahwa kandungan $\mathrm{N}$ tanah pada SPL 1 baik pada lapisan atas (0-30 $\mathrm{cm})$ dan bawah $(30-60 \mathrm{~cm})$ berada pada kategori sedang $(0,21-0,50 \%)$, artinya tanah pada SPL 1 tergolong memiliki kandungan unsur hara nitrogen hanya pada taraf cukup penyediaannya untuk pertumbuhan tanaman saja sementara nitrogen dibutuhkan dalam jumlah banyak dan merupakan unsur paling penting dalam siklus hidup tanaman. Pada SPL 2 yang berada di Desa Sukomulyo dan Desa Bendosari, menunjukkan hasil bahwa nilai $\mathrm{N}$ total pada lapisan tanah atas sebesar $0,25 \%$ dan pada lapisan tanah bawah sebesar 0,24\%. Nilai tersebut menunjukkan bahwa kandungan nitrogen tanah pada SPL 2 pada lapisan atas maupun bawah berada pada kategori sedang. Di SPL 3 yang berada di Desa Pandesari dan Desa Bendosari, menunjukkan hasil bahwa nilai N-total pada lapisan atas maupun lapisan bawah berada pada kategori rendah yaitu sebesar 0,20\% pada lapisan atas dan 0,15\% pada lapisan bawah. Di SPL 4 yang berada di Desa Pandesari dan Desa Madiredo, menunjukkan hasil bahwa nilai $\mathrm{N}$-total pada lapisan atas berada pada kategori sedang yaitu $0,22 \%$ dan rendah pada lapisan bawah yaitu 0,17\%. Dan pada SPL 5 yang berada di Desa Pandesari, menunjukkan bahwa nilai $\mathrm{N}$ total di lapisan atas berada pada kategori sedang yaitu $0,26 \%$ dan rendah pada lapisan bawah yaitu $0,19 \%$. Kandungan nitrogen yang rendah dapat disebabkan oleh $\mathrm{NO}_{3}^{-}$yang terdenitrifikasi menjadi gas $\mathrm{N}_{2}$ di lapisan reduksi dan volatilisasi gas amonia dari permukaan tanah (lapisan oksida) (D'haene et al., 2008; Noviardi, 2008).

\section{C-organik}

Berdasarkan hasil analisis yang dilakukan di kelima SPL, bahwa pada SPL 1 hasil analisis kandungan C-organik pada lapisan atas dan bawah menunjukkan nilai yang rendah hingga sangat rendah yaitu 0,51\% pada lapisan atas dan $1,77 \%$ pada lapisan bawah. Hasil analisis kandungan C-organik di SPL 2 pada lapisan atas dan bawah menunjukkan nilai yang rendah di setiap lapisan yaitu 1,24\% pada lapisan atas 


\section{Jurnal Tanah dan Sumberdaya Lahan Vol 6 No 2 : 1415-1425, 2019 e-ISSN:2549-9793, doi: 10.21776/ub.jtsl.2019.006.2.22}

dan 1,22\% pada lapisan bawah. Pada SPL 3, kandungan C-organik pada lapisan atas menunjukkan nilai yang rendah pada lapisan atas yaitu 1,91\% dan nilai yang sangat rendah pada lapisan bawah yaitu $0,36 \%$. Hasil analisis nilai C-organik DI spl 4 pada lapisan atas dan bawah menunjukkan nilai yang sangat rendah di setiap lapisan yaitu $0,53 \%$ pada lapisan atas dan 0,98\% pada lapisan bawah. Dan pada SPL 5, hasil analisis kandungan C-organik pada lapisan atas menunjukkan nilai yang sangat rendah di setiap lapisan yaitu $0,24 \%$ pada lapisan atas dan pada lapisan bawah yaitu $0,92 \%$.

\section{Rasio C/N}

Hasil analisis nilai Rasio C/N pada SPL 1 di lapisan atas berada pada kategori sangat rendah yaitu sebesar 1,88 dan kategori rendah pada lapisan bawah sebesar 5,06. Salah satu indikator yang digunakan untuk menilai kesuburan kimiawi tanah adalah $\mathrm{pH}$ tanah. Nilai Rasio $\mathrm{C} / \mathrm{N}$ pada lapisan atas dan bawah di SPL 2 berada pada kategori rendah yaitu sebesar 6,25 pada lapisan atas dan lapisan bawah sebesar 8,22. Pada SPL 3, nilai Rasio C/N pada lapisan atas berada pada kategori rendah yaitu sebesar 7,34 sedangkan lapisan bawah masuk dalam kategori sangat rendah yaitu 1,89. Kemudian pada SPL 4, nilai Rasio $\mathrm{C} / \mathrm{N}$ pada lapisan atas berada pada kategori sangat rendah yaitu 2,11 dan rendah pada lapisan bawah yaitu 5,37. Dan pada SPL 5 Nilai Rasio $\mathrm{C} / \mathrm{N}$ pada lapisan atas berada pada kategori sangat rendah di setiap lapisan yaitu 1,21 pada lapisan atas dan 4,33 pada lapisan bawah.

$p \mathrm{H}\left(\mathrm{H}_{2} \mathrm{O}\right)$ dan $p \mathrm{H}(\mathrm{KCl})$

Kemasaman tanah merupakan indikator kesuburan tanah, karena dapat mencerminkan ketersediaan hara di dalam tanah. Reaksi tanah menunjukkan sifat kemasaman atau alkalinitas tanah yang dinyatakan dengan nilai $\mathrm{pH}$. (Soewandita, 2008). Berdasarkan hasil analisis yang dilakukan di kelima SPL, bahwa pada SPL 1 menghasilkan nilai yang tergolong masam disetiap lapisan yaitu sebesar 4,8 pada lapisan atas dan lapisan bawah. Sedangkan untuk hasil analisis $\mathrm{pH} \mathrm{KCl}$ menunjukkan hasil yang tidak cukup berbeda dengan hasil analisis $\mathrm{pH} \mathrm{H}_{2} \mathrm{O}$ yaitu sebesar nilai 4.6 pada lapisan atas dan 4.5 pada lapisan bawah. . Hasil pengukuran pH di SPL 2 menghasilkan nilai yang tergolong masam disetiap lapisan yaitu sebesar 5,15 pada lapisan atas dan 5,25 pada lapisan bawah. Sedangkan untuk hasil analisis $\mathrm{pH} \mathrm{KCl}$ menunjukkan nilai yaitu sebesar 4.83 pada lapisan atas dan 5,04 pada lapisan bawah. Hasil pengukuran $\mathrm{pH} \mathrm{H}_{2} \mathrm{O}$ di SPL 3 menghasilkan nilai yang tergolong masam di setiap lapisan yaitu 4,95 pada lapisan atas dan 5,25 pada lapisan bawah. Sedangkan untuk hasil analisis pH KCl menunjukkan nilai 4.34 pada lapisan atas dan 5,04 pada lapisan bawah. Pada SPL 4, hasil pengukuran $\mathrm{pH}$ menghasilkan nilai yang tergolong masam di setiap lapisan yaitu sebesar 4,65 pada lapisan atas dan 4,75 pada lapisan bawah. Sedangkan untuk hasil analisis $\mathrm{pH} \mathrm{KCl}$ menunjukkan nilai sebesar 4.14 pada lapisan atas dan 4,32 pada lapisan bawah. Dan pada SPL 5 hasil pengukuran $\mathrm{pH} \mathrm{H}_{2} \mathrm{O}$ menghasilkan nilai yang tergolong masam di setiap lapisan yaitu 4,65 pada lapisan atas dan 4,85 pada lapisan bawah. Sedangkan untuk hasil analisis $\mathrm{pH} \mathrm{KCl}$ menunjukkan nilai yaitu 4.17 pada lapisan atas dan 4,21 pada lapisan bawah.

\section{Sebaran nitrogen tanah}

Hasil analisis tanah menunjukkan bahwa sebaran N-total pada sentra tanaman Bawang putih di Kecamatan Pujon berada pada kategori rendah hingga sedang (Gambar 1 dan Gambar 2). Analisis sebaran hara $\mathrm{N}$ dibutuhkan untuk mengetahui kandungan hara yang tersedia di dalam tanah. Peran utama N bagi tanaman adalah untuk merangsang pertumbuhan secara keseluruhan, khususnya batang, daun dan cabang (Sumiati dan Gunawan, 2007).

\section{Hubungan sifat-sifat tanah dengan N-total}

Berdasarkan hasil analisis korelasi pada Tabel 1 dan Tabel 2, menunjukkan bahwa tidak ada sifatsifat tanah yang berkorelasi nyata dengan $\mathrm{N}$-total tanah, baik pada lapisan atas maupun lapisan bawah. Hasil uji kolerasi N-total dengan $\mathrm{pH} \mathrm{H} \mathrm{H}_{2} \mathrm{O}$ pada lapisan atas dan bawah menunjukkan nilai korelasi negatif pada setiap lapisan yaitu sebesar $\mathrm{r}=-0,17$ pada lapisan atas dan $\mathrm{r}=-0,08$ pada lapisan bawah, kemudian hasil uji kolerasi $\mathrm{N}$ total dengan $\mathrm{pH} \mathrm{KCl}$ pada lapisan atas dan bawah menunjukkan nilai korelasi negatif 


\section{Jurnal Tanah dan Sumberdaya Lahan Vol 6 No 2 : 1415-1425, 2019 e-ISSN:2549-9793, doi: 10.21776/ub.jtsl.2019.006.2.22}

antara keduanya sebesar $r=-0,33$ pada lapisan atas dan pada lapisan bawah sebesar $\mathrm{r}=-0,195$ ,dimana ada indikasi bahwa jika kandungan $\mathrm{pH}$ tanah meningkat maka akan terjadi penurunan penurunan pada kandungan N-tanah, demikian juga sebaliknya.
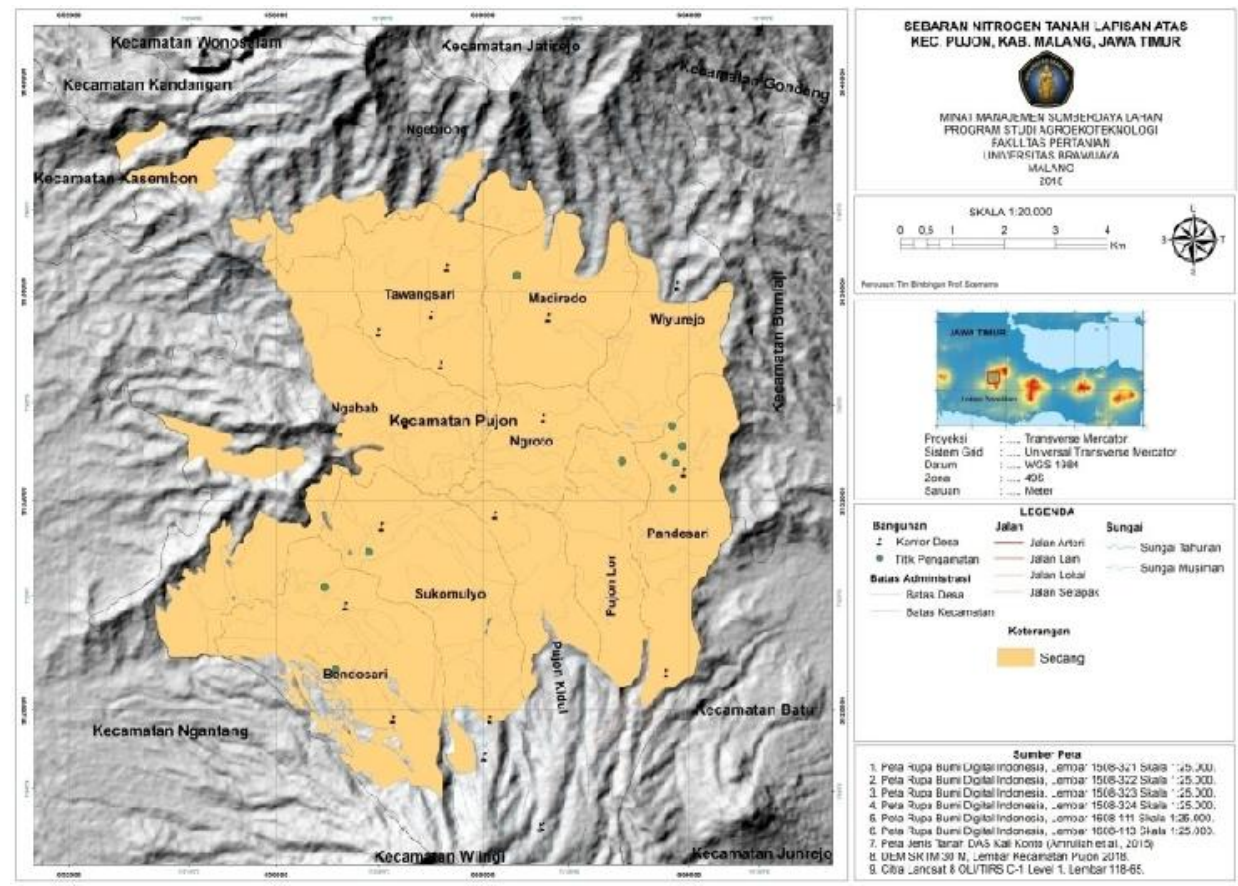

Gambar 1. Peta sebaran Nitrogen tanah pada tanaman bawang putih lapisan atas.
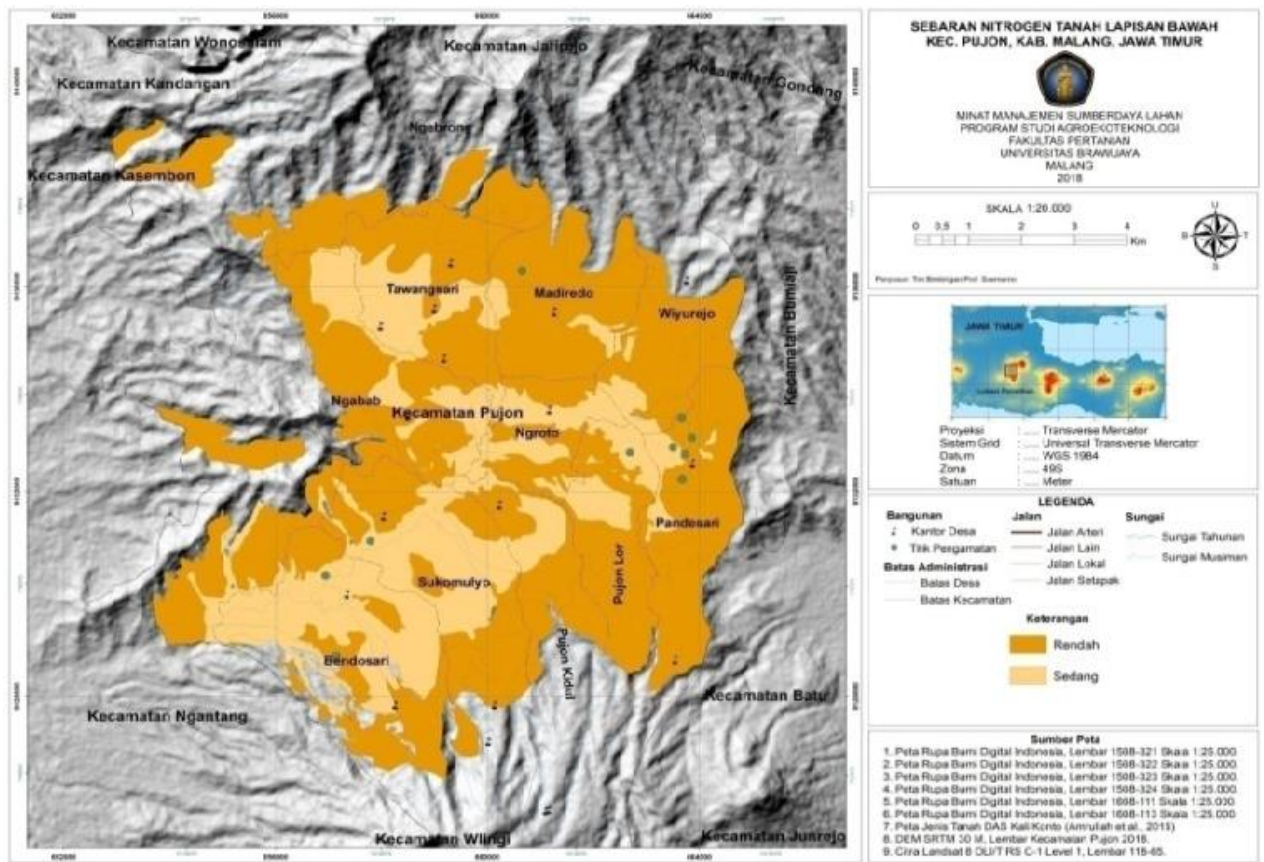

Gambar 2. Peta sebaran Nitrogen tanah pada tanaman bawang putih lapisan bawah. 


\section{Jurnal Tanah dan Sumberdaya Lahan Vol 6 No 2 : 1415-1425, 2019 e-ISSN:2549-9793, doi: 10.21776/ub.jtsl.2019.006.2.22}

Tersedianya $\mathrm{N}$ dalam tanah sangat dipengaruhi oleh $\mathrm{pH}$ tanah, dimana $\mathrm{pH}$ masam berpengaruh terhadap tersedianya unsur bagi tanah dan tanaman.

Hal ini sejalan dengan pernyataan Hardjowigeno (2003) bahwa hilangnya $\mathrm{N}$ dalam tanah dipengaruhi oleh beberapa hal, diantaranya adalah (1) digunakan oleh tanaman atau mikroorganisme, (2) pH tanah, (3) Suhu dan tata udara, dan (4) $\mathrm{N}$ dalam bentuk $\mathrm{NO}^{3-}$ (nitrat) mudah dicuci oleh air hujan (leaching). Hasil uji kolerasi N-total dengan C-organik pada lapisan atas dan lapisan bawah menunjukkan nilai korelasi positif antara keduanya yaitu sebesar $\mathrm{r}=0,495$ pada lapisan atas dan $\mathrm{r}=0,571$ pada lapisan bawah. Nilai tersebut menunjukkan bahwa jika kandungan C-organik pada tanah meningkat maka nilai N-total tanah juga akan mengalami peningkatan. Karbon merupakan komponen paling besar dalam pupuk organik dan pupuk anorganik sehingga pemberian pupuk akan meningkatkan kandungan karbon organik tanah. Kandungan C-organik tanah menunjukkan kadar bahan organik yang terkandung dalam tanah dan juga mengidentifikasikan tingkat kematangan bahan organik di dalam tanah (Harinta dan Basuki, 2018). Hasil uji kolerasi N-total dengan Rasio $\mathrm{C} / \mathrm{N}$ pada lapisan atas dan lapisan bawah menunjukkan nilai korelasi positif antara keduanya.

Tabel 1. Matriks korelasi setiap parameter pada lapisan atas.

\begin{tabular}{|c|c|c|c|c|c|c|c|c|}
\hline & $\begin{array}{c}\text { N- } \\
\text { Total }\end{array}$ & $\begin{array}{c}\mathrm{pH} \\
\mathrm{H}_{2} \mathrm{O}\end{array}$ & $\begin{array}{l}\mathrm{pH} \\
\mathrm{KCl}\end{array}$ & $\begin{array}{c}\text { C- } \\
\text { Organik }\end{array}$ & $\mathrm{C} / \mathrm{N}$ & BI & Porositas & Produksi \\
\hline $\mathrm{N}$-total & 1 & & & & & & & \\
\hline $\mathrm{pH} \mathrm{H}{ }_{2} \mathrm{O}$ & -0.17 & 1 & & & & & & \\
\hline $\mathrm{pH} \mathrm{KCl}$ & -0.33 & $0.92 * *$ & 1 & & & & & \\
\hline C-Organik & 0.49 & 0.40 & 0.41 & 1 & & & & \\
\hline $\mathrm{C} / \mathrm{N}$ & 0.31 & 0.46 & 0.47 & $0.96 * *$ & 1 & & & \\
\hline BI & -0.34 & 0.26 & 0.21 & 0.10 & 0.22 & 1 & & \\
\hline Porositas & 0.63 & 0.27 & 0.33 & 0.34 & 0.24 & $-0.76^{*}$ & 1 & \\
\hline Produksi & -0.29 & 0.16 & 0.31 & -0.04 & 0.15 & 0.45 & -0.43 & 1 \\
\hline
\end{tabular}

Keterangan: $\mathrm{r}$ tabel $5 \%=0,44: *$ : valid $; \mathrm{r}$ tabel $1 \%=0,56=*^{*}$ : sangat valid $; 0=$ tidak ada kolerasi $; 0,00$ $-0,25=$ kolerasi lemah $; 0,25-0,55=$ kolerasi sedang $; 0,55-0,75=$ kolerasi kuat $; 0,75-0,99=$ kolerasi sangat kuat ; 1 = kolerasi sempurna, nilai $+/$ - menunjukkan korelasi positif atau negative

Tabel 2. Matriks korelasi setiap parameter pada lapisan bawah.

\begin{tabular}{|c|c|c|c|c|c|c|c|c|}
\hline & N-Total & $\begin{array}{c}\mathrm{pH} \\
\mathrm{H}_{2} \mathrm{O}\end{array}$ & $\begin{array}{l}\mathrm{pH} \\
\mathrm{KCl} \\
\end{array}$ & C-Organik & $\mathrm{C} / \mathrm{N}$ & BI & Porositas & Produksi \\
\hline N-Total & 1 & & & & & & & \\
\hline $\mathrm{pH} \mathrm{H} \mathrm{H}_{2} \mathrm{O}$ & -0.08 & 1 & & & & & & \\
\hline $\mathrm{pH} \mathrm{KCl}$ & -0.19 & $0.73^{*}$ & 1 & & & & & \\
\hline C-Orga & & & & & & & & \\
\hline nik & 0.57 & -0.02 & 0.38 & 1 & & & & \\
\hline $\mathrm{C} / \mathrm{N}$ & 0.11 & -0.03 & 0.40 & $0.85^{* *}$ & 1 & & & \\
\hline BI & -0.32 & 0.14 & -0.02 & -0.49 & -0.31 & 1 & & \\
\hline Porositas & 0.32 & 0.00 & 0.14 & 0.42 & 0.24 & $-0.90 * *$ & 1 & \\
\hline Produksi & -0.30 & 0.17 & 0.40 & 0.51 & $0,82^{*}$ & -0.18 & 0.22 & 1 \\
\hline
\end{tabular}

Keterangan: $\mathrm{r}$ tabel $5 \%=0,44: *$ : valid $; \mathrm{r}$ tabel $1 \%=0,56=*^{*}$ : sangat valid $; 0=$ tidak ada kolerasi $; 0,00$ $-0,25=$ kolerasi lemah $; 0,25-0,55=$ kolerasi sedang $; 0,55-0,75=$ kolerasi kuat $; 0,75-0,99=$ kolerasi sangat kuat ; 1 = kolerasi sempurna, nilai $+/$ - menunjukkan korelasi positif atau negatif. 


\section{Jurnal Tanah dan Sumberdaya Lahan Vol 6 No 2 : 1415-1425, 2019 e-ISSN:2549-9793, doi: 10.21776/ub.jtsl.2019.006.2.22}

Hasil uji kolerasi N-total dengan Rasio C/N pada lapisan atas dan lapisan bawah menunjukkan nilai korelasi positif antara keduanya yaitu sebesar $r=0,316$ pada lapisan atas dan sebesar $r=0,110$ pada lapisan bawah ,dapat diartikan bahwa besarnya nilai $\mathrm{C} / \mathrm{N}$ rasio sangat dipengaruhi oleh nilai $\mathrm{N}$-total tanah. Hal ini sesuai dengan pernyataan Hardjowigeno (2003) bahwa jika tanah memiliki nilai $\mathrm{N}$-total tinggi maka nilai Rasio $\mathrm{C} / \mathrm{N}$ akan tinggi pula, juga tergantung dari bahan organik dalam tanah. Hasil uji kolerasi N-total dengan BI tanah menunjukkan nilai korelasi negatif di setiap lapisan yaitu $\mathrm{r}=-0,347$ pada lapisan atas dan $\mathrm{r}=-0,320$ lapisan bawah. Hasil korelasi tersebut menunjukkan bahwa adanya hubungan yang berlawanan antara BI terhadap N-total dalam tanah dimana apabila kadar BI dalam tanah meningkat maka akan diikuti dengan penurunan kandungan $\mathrm{N}$ dalam tanah. Hal ini sejalan dengan pernyataan Hillel (1980) bahwa nilai berat isi tanah akan semakin menurun dengan bertambahnya konsentrasi nitrogen dalam tanah. Hasil uji kolerasi N-total dengan Porositas pada lapisan atas dan lapisan bawah menunjukkan nilai korelasi positif di antara keduanya yaitu $\mathrm{r}=0,631$ pada lapisan atas dan $r=0,320$ pada lapisan bawah, artinya apabila nilai porositas tanah meningkat maka kandungan N-total pada tanah akan mengalami peningkatan juga. Porositas tanah juga mencerminkan kemampuan tanah menyerap air dan erat kaitannya dengan bobot isi tanah. Kandungan nitrogen tanah yang tinggi dapat meningkatkan kualitas sifat fisik tanah, melalui aktivitas mikroorganisme tanah yang dapat membantu agregasi tanah (Bailey et al., 2013; Blaud et al., 2014).

\section{Hubungan dosis pupuk $\mathbf{N}$ yang ditambahkan dari pupuk anorganik dengan $\mathbf{N}$-total tanah}

Jenis tanah yang ada di sentra Bawang putih Kecamatan Pujon adalah Inceptisols. Salah satu upaya yang dapat dilakukan untuk meningkatkan kesuburan tanah Inseptisols, yaitu dengan menambahkan bahan organik dan pupuk $\mathrm{N}$ dengan dosis yang tepat. Pengelolaan tanah dengan manajemen pemupukan anorganik saja dianggap kurang efisien, karena pupuk kimia dianggap melepaskan nitrogen lebih tinggi, bertahan untuk waktu yang lebih singkat, dan memiliki kandungan nitrogen yang cepat habis (Al Batania et al., 2016). Berdasarkan hasil analisis jumlah dosis pupuk $\mathrm{N}$ yang ditambahkan dari pupuk anorganik di setiap titik SPL (Tabel 15), menghasilkan bahwa jumlah dosis pupuk $\mathrm{N}$ yang diberikan dalam tanah tidak memberikan perubahan yang signifikan pada kandungan $\mathrm{N}$-total tanah.

Pada titik 1.2 dosis pupuk $\mathrm{N}$ dari pupuk anorganik senilai $42 \%$ hanya berasal dari pupuk ZA sebesar $100 \mathrm{~kg}$ ha-1, pada titik 1.2 dosis pupuk $\mathrm{N}$ dari pupuk anorganik senilai $42 \%$ hanya berasal dari pupuk ZA sebesar $100 \mathrm{~kg}$ ha-1, pada titik 2.2 dan titik 3.1 dosis pupuk $\mathrm{N}$ dari pupuk anorganik senilai $75 \%$ hanya berasal dari pupuk Phonska sebesar $500 \mathrm{~kg}$ ha1 , pada titik 3.2 dosis pupuk $\mathrm{N}$ dari pupuk anorganik senilai $90 \%$ berasal dari pupuk Phonska sebesar $300 \mathrm{~kg}$ ha-1 dan pupuk NPK Mutiara sebesar $350 \mathrm{~kg}$ ha-1. pada titik 4.1 dosis pupuk $\mathrm{N}$ dari pupuk anorganik senilai $75 \%$ berasal dari pupuk Phonska sebesar 200 kg ha-1 dan pupuk ZA sebesar $150 \mathrm{~kg}$ ha-1, pada titik 4.2 dosis pupuk $\mathrm{N}$ dari pupuk anorganik senilai $92 \%$ berasal dari pupuk Phonska ebesar $120 \mathrm{~kg}$ ha-1, pupuk ZA sebesar $100 \mathrm{~kg}$ ha-1 dan pupuk NPK Mutiara sebesar $200 \mathrm{~kg}$ ha-1, pada titik 4.2 dosis pupuk $\mathrm{N}$ dari pupuk anorganik senilai $92 \%$ berasal dari pupuk Phonska sebesar $120 \mathrm{~kg}$ ha-1, pupuk ZA sebesar $100 \mathrm{~kg}$ ha-1 dan pupuk NPK Mutiara sebesar $200 \mathrm{~kg}$ ha-1, sedangkan pada titik 5.1 dan 5.2 dosis pupuk $\mathrm{N}$ dari pupuk anorganik senilai 45\% hanya berasal dari pupuk Phonska sebesar $300 \mathrm{~kg}$ ha-1. Dosis pupuk $\mathrm{N}$ yang terbanyak terdapat di SPL 4 sebesar 92\%, namun kandungan N-total di SPL tersebut masuk dalam kategori rendah dan sedang. Menurut Harinta dan Basuki, 2018), bahwa penggunaan pupuk anorganik dapat menyebabkan kandungan unsur hara dalam tanah lebih meningkat tetapi tidak akan bertahan dalam waktu yang lama dan residu pupuk anorganik yang ada dalam tanah akan mengakibatkan terhambatnya proses dekomposisi bahan organik secara alami oleh mikroorganisme tanah. Hubungan antara penambahan dosis pupuk $\mathrm{N}$ dari pupuk anorganik dengan $\mathrm{N}$-total dapat dilihat pada Gambar 3. Penambahan dosis pupuk N 
memiliki hubungan yang sedang dengan $\mathrm{N}$ total $\left(\mathrm{R}^{2}=0.488\right)$ yang berarti penambahan dosis pupuk $\mathrm{N}$ dari pupuk anorganik hanya mempengaruhi $48 \%$ pada nilai $\mathrm{N}$-total tanah. Hasil analisis tersebut dapat disebabkan oleh pengaplikasian pupuk $\mathrm{N}$ yang kurang tepat oleh petani di lahan. Petani di kelima SPL pada sentra tanaman Bawang putih Kecamatan Pujon cenderung mengaplikasikan pupuk dengan cara disebar di atas permukaan tanah.
Menurut Sancez (1992), pada saat pemupukan, sebaiknya pupuk $\mathrm{N}$ ditempatkan di bawah permukaan tanah dengan kedalaman kurang lebih $5 \mathrm{~cm}$ yang dapat menyebabkan tingkat kehilangan $\mathrm{N}$ rendah karena penguapan sangat kecil, sehingga tetap tersedia di dalam tanah. Faktor dosis pupuk biasanya berpengaruh terhadap nilai serapan $\mathrm{N}$ oleh tanaman bawang (Hernández et al., 2000; Zaman et al., 2011; Bo et al., 2016).

Tabel 3. Jumlah dosis pupuk $\mathrm{N}$ yang ditambahkan dari pupuk anorganik.

\begin{tabular}{|c|c|c|c|c|c|c|c|}
\hline \multirow[t]{2}{*}{ SPL } & \multirow[t]{2}{*}{ Titik } & \multirow{2}{*}{$\begin{array}{l}\text { Phonska } \\
\left(\mathrm{kg} \mathrm{ha}^{-1}\right)\end{array}$} & \multirow{2}{*}{$\begin{array}{c}\mathrm{ZA} \\
\left(\mathrm{kg} \mathrm{ha}^{-1}\right)\end{array}$} & \multirow{2}{*}{$\begin{array}{c}\text { NPK } \\
\text { Mutiara } \\
\left(\mathrm{kg} \mathrm{ha}^{-1}\right)\end{array}$} & \multirow{2}{*}{$\begin{array}{l}\text { Dosis N } \\
\left(\mathrm{kg} \mathrm{ha}^{-1}\right)\end{array}$} & \multicolumn{2}{|c|}{ N-total (\%) } \\
\hline & & & & & & $(0-30 \mathrm{~cm})$ & $(30-60 \mathrm{~cm})$ \\
\hline \multirow{2}{*}{1} & 1 & - & - & - & - & \multirow{2}{*}{0.25} & \multirow{2}{*}{0.26} \\
\hline & 2 & - & 100 & - & $42 \%$ & & \\
\hline \multirow{2}{*}{2} & 1 & - & 100 & - & $42 \%$ & \multirow{2}{*}{0.25} & \multirow{2}{*}{0.24} \\
\hline & 2 & 500 & - & - & $75 \%$ & & \\
\hline \multirow{2}{*}{3} & 1 & 500 & - & - & $75 \%$ & \multirow{2}{*}{0.20} & \multirow{2}{*}{0.15} \\
\hline & 2 & 300 & - & 350 & $90 \%$ & & \\
\hline \multirow{2}{*}{4} & 1 & 200 & 150 & - & $75 \%$ & \multirow{2}{*}{0.22} & \multirow{2}{*}{0.17} \\
\hline & 2 & 120 & 100 & 200 & $92 \%$ & & \\
\hline \multirow{2}{*}{5} & 1 & 300 & - & - & $45 \%$ & \multirow{2}{*}{0.26} & \multirow{2}{*}{0.19} \\
\hline & 2 & 300 & - & - & $45 \%$ & & \\
\hline
\end{tabular}

Keterangan: Dosis N dalam $50 \mathrm{~kg} \mathrm{ha}{ }^{-1}$ pupuk : $\mathrm{ZA}=21 \%$; Phonska $=15 \%$; NPK Mutiara $=15 \%$

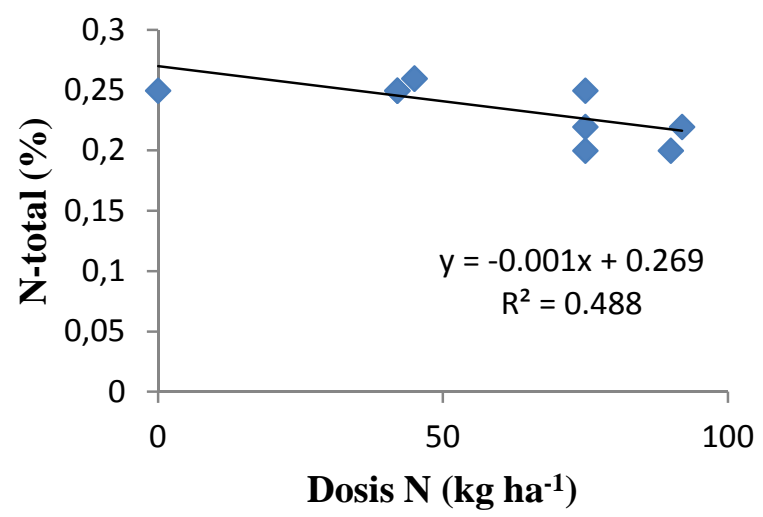

Gambar 3. Pengaruh dosis pupuk N (X) yang ditambahkan dari pupuk anorganik terhadap kandungan Ntotal tanah $(\mathrm{Y})\left(\mathrm{Y}=-0.001 \mathrm{X}+0.269 ; \mathrm{R}^{2}=0.488\right)$

Tanaman bawang putih memerlukan hara $\mathrm{N}$, $\mathrm{P}$, dan $\mathrm{K}$ untuk mendukung proses pertumbuhannnya, namun dosis pemupukan $\mathrm{N}$ harus sesuai dengan fase pertumbuhan tanaman (Diriba-Shiferaw et al., 2015).
Tersedianya $\mathrm{N}$ tanah dari pupuk anorganik biasanya hanya dalam jangka pendek, sehingga hara yang dapat dimanfaatkan oleh tanaman hanya sebagian kecil saja dan sebagian lagi hilang ke luar zone akar tanaman atau 


\section{Jurnal Tanah dan Sumberdaya Lahan Vol 6 No 2 : 1415-1425, 2019 e-ISSN:2549-9793, doi: 10.21776/ub.jtsl.2019.006.2.22}

menguap ke atmosfir (Bordoloi et al., 2013; Mariano et al., 2019). Tujuan teknologi pemupukan $\mathrm{N}$ yang tepat dalam budidaya bawang putih adalah memperbesar jumlah hara pupuk yang tinggal dalam zone akar tanaman, dan meminimumkan kehilangan hara ke luar zone akar tanaman (Wang dan Zhou, 2013; Chen et al., 2016; ).

\section{Hubungan sifat-sifat tanah dengan produksi bawang putih}

Berdasarkan hasil analisis korelasi pada Tabel 1 dan Tabel 2 menunjukkan bahwa parameter sifat tanah yang berkolerasi nyata dengan produksi hanyalah Rasio $\mathrm{C} / \mathrm{N}$ pada lapisan bawah saja yaitu sebesar $r=0,82$ ( $r$ tabel $=0,44$ ) yang artinya terdapat korelasi yang sangat kuat antara keduanya, dimana jika nilai Rasio $\mathrm{C} / \mathrm{N}$ pada lapisan bawah meningkat maka akan terjadi peningkatan terhadap nilai produksi, sedangkan korelasi antara produksi dengan Rasio C/N pada lapisan atas menunjukkan nilai korelasi positif dengan tingkat keeratan yang rendah yaitu 0,150. Berdasarkan hasil analisis hubungan antara Rasio C/N dengan Produksi pada Gambar 4, menunjukkan hasil bahwa peningakatan Rasio $\mathrm{C} / \mathrm{N}$ dapat meningkatkan nilai produksi $\left(\mathrm{R}^{2}=0,68\right)$ yang berarti $68 \%$ dipengaruhi oleh faktor peningkatan Rasio $\mathrm{C} / \mathrm{N}$.

Hasil analisis hubungan antara kedua parameter tesebut sesuai dengan pernyataan Hardjowigeno (2003) bahwa bahan organik tanah memegang peranan penting dalam meningkatkan dan mempertahankan kesuburan kimia, fisika dan biologi tanah, yang akan menentukan produktivitas tanaman dan keberlanjutan penggunaan lahan untuk pertanian. Salah satu faktor lingkungan yang menentukan laju pertumbuhan dan perkembangan tanaman, dan produksi tanaman adalah tersedianya unsur-unsur hara yang cukup di dalam tanah, termasuk nilai $\mathrm{C} / \mathrm{N}$ rasio dalam tanah (Adem dan Tadesse, 2014; Anand et al., 2017).

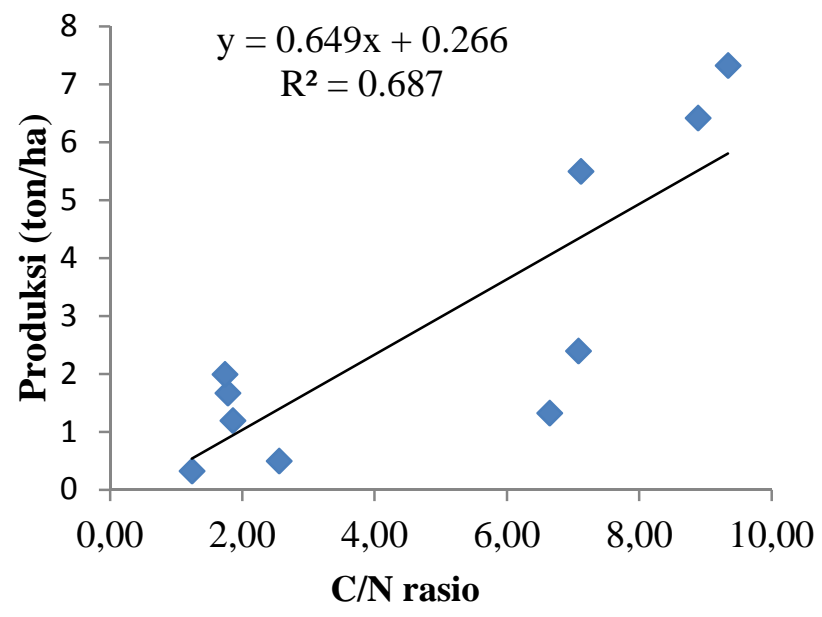

Gambar 4. Pengaruh Rasio C/N tanah lapisan bawah $(\mathrm{X})$ terhadap Produksi Bawang putih $(\mathrm{Y})$ $(\mathrm{Y}=0.649+0.266 ; \mathrm{R} 2=0.687)$

Petani bawang putih seringkali melakukan pemupukan tanpa memperhatikan fase pertumbuhan tanaman bawang putih, sehingga peningkatan hasil umbi belum optimal (Bertoni et al., 1992; Kuldeep et al., 2012). Bawang putih mempunyai sistem perakaran yang sederhana dan zone perakarannya sangat dangkal; hal ini menyebabkan munculnya masalah-masalah serius dalam penyerapan unsur hara selama pertumbuhannya (Nackley et al., 2016). Pada awal pertumbuhannya, tanaman bawang putih memerlukan sedikit $\mathrm{N}$, sedangkan pada saat memasuki fase pertumbuhan cepat, jumlah $\mathrm{N}$ yang dibutuhkan lebih banyak. Untuk dapat menghasilkan umbi yang optimal, petani bawang putih harus memperhatikan populasi 


\section{Jurnal Tanah dan Sumberdaya Lahan Vol 6 No 2 : 1415-1425, 2019 e-ISSN:2549-9793, doi: 10.21776/ub.jtsl.2019.006.2.22}

tanaman serta waktu pemupukan $\mathrm{N}$ yang tepat sesuai dengan kebutuhan $\mathrm{N}$ tanaman (Sebnie et al., 2018). Aplikasi kombinasi pupuk anorganik dan organik, seperti urea dan TSP dengan pupuk kandang seringkali dapat meningkatkan prtoduktivitas tanaman bawang putih (Zaki et al., 2014; Shafeek et al., 2015; Acharya dan Kumar, 2018).

\section{Kesimpulan}

Kandungan N-tanah pada sentra tanaman bawang putih di Kecamatan Pujon berada pada kategori "Rendah" hingga "Medium" atau "Sedang". Kandungan N-tanah pada lapisan topsoil (0-30 cm) di kelima SPL adalah "Sedang", sedangkan kandungan N-tanah pada lapisan subsoil $(30-60 \mathrm{~cm})$ di kelima SPL adalah "Rendah" dan "Sedang". Hubungan antara kandungan N-tanah dengan sifat-sifat tanah menunjukkan korelasi yang tidak signifikan, sedangkan produksi bawang putih berkorelasi signifikan dengan Rasio $\mathrm{C} / \mathrm{N}$ tanah lapisan subsoil $(30-60 \mathrm{~cm})\left(\mathrm{r}=0,82^{* *}\right)$.

\section{Daftar Pustaka}

Acharya, S. and Kumar, H. 2018. Effect of some organic manure on growth and yield of garlic in greenhouse condition at cold desert high altitude Ladakh Region. Defence Life Science Journal 3(2): 100-104

Adem, B.E. and Tadesse, S.T. 2014. Evaluating the role of nitrogen and phosphorous on the growth performance of garlic (Allium sativum L.). Asian Journal of Agricultural Research 8: 211-217.

Al-Batania, B.B., Young, T.M. and Ranieri, E. 2016. Effects of compost age on the release of nutrients. International Journal of Soil and Water Conservation Research 4: 230-236.

Anand,M., A. Sankari and B. Anita. 2017. Influence of Integrated Nutrient Management for Garlic under Nilgiris Condition. Intetrnatonal Journal of Current Microbiology and Applied Sciences 6(12): 3833-3838.

Assefa, A.G., Misgina, S.H. and Abrha, Y.W. 2015. Effect of inorganic and organic fertilizers on the growth and yield of garlic crop (Allium sativum L.) in northern Ethiopia. Journal of Agricultural Science 7(4): 80-86.

Badan Pusat Statistik dan Direktorat Jendral Hortikultura. 2015. Produksi Bawang Merah Menurut Provinsi Tahun 2009-2013. Kementrian Pertanian Republik Indonesia.

Bailey, V.L., Fansler, S.J., Stegen, J.C., McCue, L.A. 2013. Linking microbial community structure to betaglucosidic function in soil aggregates. ISME $\mathrm{J} 7$ : 2044-2053.
Bertoni, G., Morard, P., Soubieille, C. and Llorens, J.M. 1992. Growth and nitrogen nutrition of garlic (Allium sativum L.) during bulb development. Scientia Horticulturae 50: 187-195.

Blaud, A., Chevallier, T., Virto, I., Pablo, A.-L., Chenu, C. and Brauman, A. 2014. Bacterial community structure in soil microaggregates and on particulate organic matter fractions located outside or inside soil macroaggregates. Pedobiologia 57: 191-194

Bo, L., Zhang, Y., Y.Li, Luo, J., Sun, M., Zhon, Z. and Jing, Y. 2016. Effects of nitrogen management on garlic yield, economic benefit and soil apparent nutrient balance. Journal of Advances in Agriculture 6(1): 883-887.

Bordoloi, L.J., A. Singh, M.Kumar, Patiram and S.Hazarika. 2013. Evaluation of nitrogen availability indices and their relationship with plant response on acidic soils of India. Plant Soil and Environment, 59(6):235-240.

Chen, Z., Wang, H., Liu, X., Liu, Y., Gao, S. and Zhou, J. 2016. The effect of $\mathrm{N}$ fertilizer placement on the fate of urea- ${ }^{15} \mathrm{~N}$ and yield of winter wheat in Southeast China. PLoS ONE, 11(4): e0153701.

D'haene, K., Vandenbruwane, J., De Neve, S., Gabriels, D., Salomez, J. and Hofman, G. 2008. The effect of reduced tillage on nitrogen dynamics in silt loam soils. European Journal of Agronomy 28: 449-460.

Diriba-Shiferaw, G., Nigussie-Dechassa, R., Woldetsadik, K., Tabor, G. and Sharma, J.J. 2015. Effect of nitrogen, phosphorus, and sulphur fertilizers on growth, yield, and economic returns of garlic (Allium sativum L.). African Journal of Agricultural Research $4(2), 10-22$.

Djaenudin, D., Marwan, H., Subagjo, H. dan Hidayat, A. 2011. Petunjuk Teknis Evaluasi Lahan Untuk Komoditas Pertanian. Balai Besar Litbang Sumberdaya Lahan Pertanian, Badan Litbang Pertanian, Bogor.

Hardjowigeno, S. 2003. Ilmu Tanah. Jakarta ID) : Akademika Pressindo.

Harinta, Y.W. dan Basuki, J.S. 2018. Potensi pengembangan bawang putih sebagai komoditas unggulan di Kabupaten Karanganyar. Agrisaintifika 2(2): 123-130.

Hariwibowo, P.A., Anindita, R. dan Suhartini. 2014. Permintaan bawang putih di Indonesia. Habitat, $\mathrm{XXV}(2): 78-85$.

Hernández, M.I.G., Del Pozo, A., Gallet, M. and Vidal I. 2000. Nitrogen uptake and use efficiency in garlic estimated by $15 \mathrm{~N}$-labelling method. Conference Paper : Proceeding of the Third International Symposium on Edible Alliaceae, At Athens, Georgia, USA, Volume: 81-85.

Hillel, D. 1980. Fundamental of Soil Physics. Academic Press Inc. London.

Kuldeep, S., Patel, N.M., Bhadhauria, H.S. and Wankhade, V.R. 2012. Effect of integrated nutrient management on growth and yield of garlic (Allium sativum L.). Advance Research Journal of Crop Improvement 3(2): 164-166.

Mariano, E., de Sant Ana-Filho, C.R., Bortoletto-Santos, R., Bendassolli, J.A. and Trivelin, P.C.O. 2019. 
Ammonia losses following surface application of enhanced-efficiency nitrogen fertilizers and urea. Atmospheric Environment 203: 242-251.

Mehran, E., Kesumawati dan Sufardi. 2016. Pertumbuhan dan hasil beberapa varietas bawang merah (Allium ascalonicum L) pada tanah aluvial akibat pemberian berbagai dosis pupuk NPK. Jurnal Floratek 11(2): 117-133.

Nackley, L.L., Jeong, J.H., Oki, L.R. and Kim, S.-H. 2016. Photosynthetic acclimation, biomass allocation, and water use efficiency of garlic in response to carbon dioxide enrichment and nitrogen fertilization. Journal of the American Society for Horticulture Science 141(4): 373-380.

Noviardi H. 2008. Laju Mineralisasi $\mathrm{N}^{-\mathrm{NH}_{4}}$ dan $\mathrm{N}-\mathrm{NO}_{3}$ Tanah Andisol pada Pertanian Organik dan Konvensional yang ditanami kentang. ITB. Bandung.

Sanchez, P.A. 1992. Sifat dan Pengelolaan Tanah Tropika, jilid 2/ Pedro A Sanchez: Terjemahan Amir Hamzah. Bandung: Penerbit ITB.

Sarwadana, S.M. dan Gunadi, I.G.A 2007. Potensi pengembangan bawang putih (Allium sativum L.) dataran rendah varietas lokal Sanur. Agritrop 26(1): 19-23.

Sebnie, W., Mengesha, M., Girmay, G. and Feyisa, T. 2018. Response of garlic (Allium sativum L.) to nitrogen and phosphorus under irrigation in Lasta district of Amhara Region, Ethiopia. Cogent Food \& Agriculture 4: 1-8.

Shafeek, M.R., Ali, A.H., Mahmoud, A.R., Hafez, M.M. and. Rizk, F.A. 2015. Improving growth and productivity of garlic plants (Allium sativum L.) as affected by the addition of organic manure and humic acid levels in sandy soil conditions. Internatonal Journal of Current Microbiology and Applied Sciences 4(9): 644-656
Soewandita, H. 2008. Studi kesuburan tanah dan analisis kesesuaian lahan untuk komoditas tanaman perkebunan di Kabupaten Bengkalis. Jurnal Sains dan Teknologi Indonesia 10 (2) : 128-133

Sugiyono. 2003. Metode Penelitian Bisnis. Cetakan Kelima. Bandung: CV. Alfabeta

Sumiati, E dan Gunawan, O 2007, Aplikasi pupuk hayati mikoriza untuk meningkatkan efisiensi serapan unsur hara NPK serta pengaruhnya terhadap hasil dan kualitas umbi bawang putih, Jurnal Hortikultura 17(1): 34-42.

Tenaya, I.M.N. 2001. Karakteristik pertumbuhan tanaman bawang putih pada berbagai kerapatan populasi. Jurnal Agritrop 20(1) : 10-15.

Wang, H. and Zhou J. 2013. Root-zone fertilization-A key and necessary approach to improve fertilizer use efficiency and reduce non-point source pollution from the cropland. Soils 05:785-790

Wisardja, I.P., Lana, W. dan Rusdianta, I.G. 2017. Pertumbuhan dan hasil tanaman bawang putih (Allium sativum L.) varietas Lumbu Putih akibat penggunaan dosis pupuk organik dan kerapatan tanaman. Majalah Ilmiah Untab 14(2): 209-215.

Zaki, H.E.M., Toney, H.S. and Abd Elraouf, R.M. 2014. Response of two garlic cultivars (Allium sativum L.) to inorganic and organic fertilization. Nature and Science 12(10): $52-60$.

Zaman, M.S., Hashem, M.A., Jahiruddin, M. and Rahim, M.A. 2011. Effect of nitrogen for yield maximization of garlic in old Brahmaputra Flood Plain soil. Bangladesh Journal of Agriculture Research 36(2): 357-367. 